\title{
The Implementation of the End-User Computing Satisfaction Model into SCeLE: A Study of the Undergraduate Program of the Accounting Department in Universitas Indonesia
}

\author{
Mohamad Jatiardi Fitriantoro ${ }^{1}$, Nurul Husnah ${ }^{1 *}$ \\ ${ }^{1}$ Faculty of Economics and Business, Universitas Indonesia, Depok 16424, Indonesia \\ *nurul.husnah@ui.ac.id
}

\begin{abstract}
This research aims to analyze the factors that affect the user satisfaction of the Student Centered e-learning Environment (SCeLE) in the Undergraduate Student of Accounting Department of the Faculty of Economics and Business, Universitas Indonesia, by implementing the End-User Computing Satisfaction (EUCS) model. The analysis was conducted using the Structural Equation Modeling Partial Least Square (SEM-PLS) method. The results showed that improving all of the factors under analysis (content, accuracy, format, ease of use, and timeliness) affected the SCeLE's user satisfaction positively.
\end{abstract}

Keywords: User Satisfaction; End-User Computing Satisfaction (EUCS) Model; E-Learning.

\section{INTRODUCTION}

E-learning is a learning process conducted by systematically utilizing information, communication, and technology (ICT). In the accounting field, e-learning has been used by many institutions, including educational institutions. An Australian organization called ICAA has been using an e-learning method known as the Flexible Online Learning Solution as a means of facilitating its members to learn quickly and flexibly in order to face the rapidly changing needs of its members, who are accountants ${ }^{1}$. Ireland's CPA offers an e-learning method to its members as one of the options which may be used as an alternative to conventional learning ${ }^{2}$. Finally, PWC Indonesia provides a financial accounting training service to companies in need, in the form of an e-learning method named Comperio ${ }^{3}$.

Among universities, e-learning is widely-known as the Learning Management System (LMS), which focuses primarily on assisting students in the learning process ${ }^{4}$. From the researcher's point of view, e-learning has become an interesting topic for study. Previous research conducted in the United Kingdom, New Zealand, and Australia has found that student perception of e-learning was positively affected by three forms of LMS (the use of lesson records, the use of bulletin boards and discussion forums, and the use of other LMS features) $)^{5}$. Another study conducted in Australia found that students believe that using e-learning methods can provide them with the flexibility to work at a pace of learning that better fits their learning ability. However, it was also discovered that the students believe that e-learning can reduce their internal motivation for learning in class ${ }^{6}$.

Based on the results of previous studies relating to this topic, e-learning is considered to be helpful in assisting the learning process because this method provides flexibility and overcomes all of the limitations of study, including time and place. Although, as aforementioned, some research has identified the negative impact of elearning, this method is beginning to be considered as one of the integral parts of the education system. So, in order to further explore the benefits of e-learning, the effectiveness of current e-learning practices will be evaluated and recommendations will be made regarding a better learning process for students.

The purpose of this study was to determine which factors affect the satisfaction of Student Centered elearning Environment (SCeLE) users by employing the EUCS model developed by Doll and Torkzadeh ${ }^{7}$. SCeLE, a form of LMS used by Universitas Indonesia (UI), is an information system built on an open source-based application called Moodle. SCeLE was designed to serve as a supplement to classroom activities ${ }^{8}$.

\section{LITERATURE REVIEW AND HYPOTHESIS DEVELOPMENT}

A system is defined as two or more components that are interconnected with each other to achieve a specific goal, while information is defined as data that have been processed to create meaning so that they can be useful in decision-making ${ }^{9}$. An information system has at least four components that are interconnected to one another ${ }^{9}$. Based on the Harold-Leavitt model, the four components of an information system are digital technology, people, jobs, and a structure, each of which are interconnected.

E-learning is a method designed with the purpose of realizing distance learning through the use of technology which can be used in the classroom and even outside the classrom ${ }^{10}$. At the college and university level, 
e-learning is known as the LMS and focuses mainly on assisting students in the learning process ${ }^{11}$. In Indonesia, elearning has been implemented in several universities, such as the University of Gadjah Mada and UI. The University of Gadjah Mada has adopted a form of e-learning named ELISA (e-learning System for Academic Community) as their alternative teaching method ${ }^{12}$. Meanwhile, UI uses an e-learning system named SCeLE.

SCeLE is a form of LMS used by UI. SCeLE is an information system that is built on an open source-based application called Moodle. SCeLE is only accessible to students, faculty and administrators assigned to manage SCeLE. The features of SCeLE include the presentation of materials, online discussion forums, questionnaires (for lecturers only), a task uploading section, an exams and quizzes page, upload and download forms, and a chat room $^{8}$.

End-User Computing Satisfaction (EUCS) is a model developed by Doll and Torkzadeh ${ }^{7}$. The model is commonly used to measure the satisfaction of information system users based on their perception of the quality of the information system ${ }^{7}$. The five factors assessed in the EUCS model are content (C), accuracy (A), format (F), ease of use (E), and timeliness (T), as shown in Figure $1^{7}$.

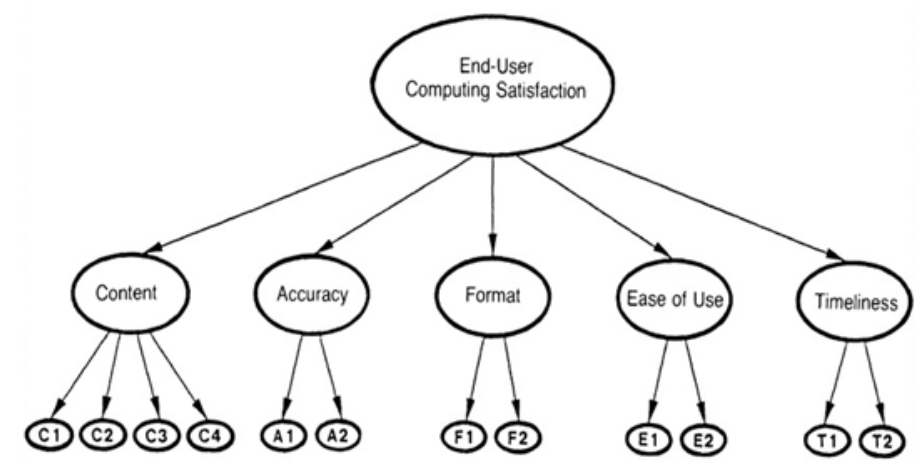

Fig.1. End-User Computing Satisfaction Model

A study was conducted in Finland using the EUCS model to measure satisfaction in online bank services. The research found that improving the content, ease of use and accuracy factors affected the success of the information system positively ${ }^{13}$. In Indonesia, Sutiono and Muldiyanto used a modified EUCS model to evaluate the e-learning user satisfaction factors at the Center for Education and Training of BPPK in 2013. The research found that the accuracy, timeliness, and service factors were most relevant in affecting information system user satisfaction ${ }^{14}$.

The hypotheses of this study are as follows:

H1: The content of the information system affects SCeLE end-user satisfaction positively.

H2: The accuracy of the information system affects SCeLE end-user satisfaction positively.

H3: The format of the information system affects SCeLE end-user satisfaction positively.

H4: The ease of use of the information system affects SCeLE end-user satisfaction positively.

H5: The timeliness of the information system affects SCeLE end-user satisfaction positively.

\section{RESEARCH METHOD}

This research is an empirical study which uses a survey as the research strategy. The survey was conducted by distributing questionnaires to the respondents. The research respondents were undergraduate students of the Department of Accounting at the Faculty of Economics and Business, UI, who were registered as students in the accounting course and used SCeLE during 2015. The data were analyzed using the Structural Equation Modeling Partial Least Square (SEM-PLS) method, commonly known as Path Modeling.

In the SEM method, constructs are divided into two types, namely exogenous and endogenous constructs. Exogenous constructs are those which can stand on their own and are determined by factors that lie outside the research model. Exogenous constructs can be said to be a collection of independent variables (multi-item independent variables). Conversely, endogenous constructs are a collection of dependent variables (multi-item dependent variable), that is, constructs that are determined by factors in a research model ${ }^{15}$. In this study, the endogenous variable is the SCeLE user satisfaction, while the exogenous variables are the content, accuracy, format, ease of use, and timeliness factors.

This study employed a modified questionnaire, based on Doll and Torkzadeh ${ }^{7}$, using a Likert scale with a range of 1 to 5. The range of values was determined based on the degree of agreement from the users' perceptions, ranging from strongly disagree to strongly agree. 


\section{RESULTS AND DISCUSSION}

There was a final total of 278 respondents. Initially, questionnaires were distributed to 600 respondents. Of these, 578 respondents returned the questionnaire. After these were checked, only 278 of the respondents' questionnaires could be used in the study. A total of 109 respondents (39\%) were male, the remaining 169 (61\%) were female. The age ranged from 18 to 24 years old. The respondents were second to fourth year students in the Undergraduate Accounting Program of UI; 54 respondents were second year students, 110 respondents were third year students, and 114 respondents were fourth year students.

The descriptive statistical data regarding the five constructs of the EUCS model are shown in Figure 2. The construct which had the highest average respondent perception value was format, followed by the constructs of content, accuracy, timeliness, ease of use, and user satisfaction. These remaining five constructs resulted in averages ranging from 2.51 to 3.50 .

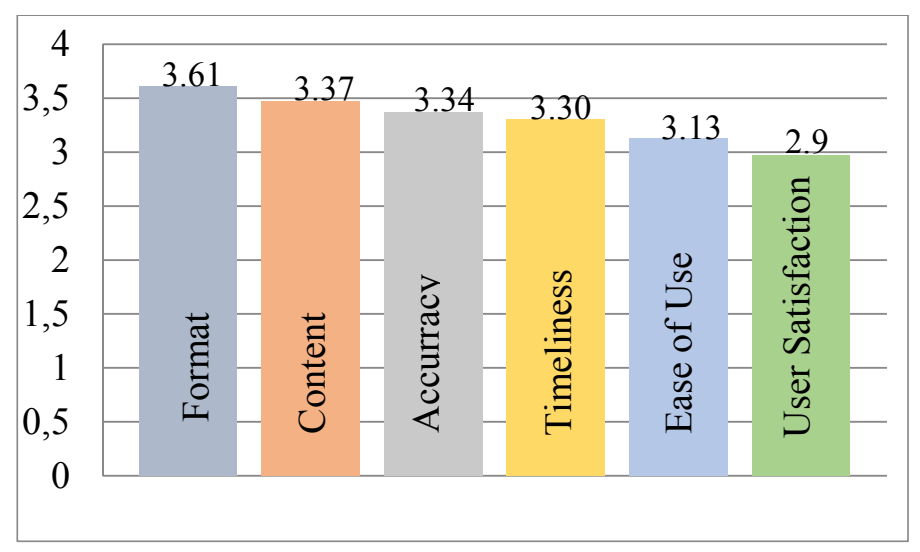

Fig.2. Average Value of Constructs

Prior to performing PLS analysis, the validity and reliability of the data were first tested. In order to measure the validity, the KMO and Bartlett Test of Sphericity and loading factors were employed. Meanwhile, Cronbach's alpha and composite reliability were used to measure the reliability. Each of the constructs met the requirement of the KMO and Bartlett Test of Sphericity, namely that the KMO value should not be smaller than 0.5 and the Bartlett value should not be greater than 0.05 in order for the construct to be considered as valid ${ }^{16}$. The minimum value of loading factors allowed to be included in the SEM-PLS was $0.5^{16}$. It can be concluded that all indicators were valid and were suitable to be included in the path analysis of SEM-PLS. The value of Cronbach's alpha and composite reliability for each of the constructs was greater than 0.6. Therefore, it can be concluded that all indicators were reliable.

The evaluation of the complete model was undertaken to assess its overall performance by using the Goodness of Fit (GoF) index. From the calculation, it was found that the average value of $\mathrm{R}$ squared and communality amounted to 0.2654 and 0.7114 , respectively. The values of $\mathrm{R}$ squared and communality were then added into the GoF index formula, as follows:

$G o F=\sqrt{\varnothing R^{2} \times \varnothing C o m}$

From the formula above, the GoF index was found to have a value of 0.4345 . This result proved that this research model surpassed the 0.36 boundary, which is considered to be the minimum value of a good research model. ${ }^{15,16}$

Furthermore, the researchers also evaluated the measurement model (outer model). This evaluation was carried out with the aim of determining the strength of the relationship between constructs which are within the same indicator. The analysis of an outer model is generally divided into two methods of measurement, the convergent validity and discriminant validity, which each employ different approaches. Convergent validity is measured using the validity indicator, reliability indicator, and Average Variance Extracted (AVE).

The validity indicator can be evaluated by examining the value of the loading factors and t-statistics. The minimum value of loading factors that could be included in a model is 0.5 . Meanwhile, the minimum value of the tstatistics that reflects the indicator that has sufficient significance to the construct is $2.0^{16,17}$. In this study, each of the indicators had loading factors above 0.5 . Indeed, the indicator with the greatest loading factors, A2, had a value of 0.92. Meanwhile, the indicator with the smallest loading factors was $\mathrm{C} 1$, with a value of 0.6654 . Each of the indicators had t-statistics above 2.0. Moreover, the t-statistics value of indicator S4 reached 13.8648. These results prove that each of the indicators had a significant relationship with the aligned construct. After measuring the convergent validity from the perspective of the validity indicator, the results could be confirmed using the reliability indicator and the value of AVE. 
To measure the reliability indicators, composite reliability was used, whereas, for the Average Variance Extracted, the AVE value was used. The minimum value of the composite reliability allowed is equal to the minimum value that is required by Cronbach's alpha approach, which is 0.6. Meanwhile the minimum value of AVE should be $0.5^{16,17}$. It was found that each of the constructs in this study had a composite reliability above 0.6. Moreover, each of the constructs in this model had a composite reliability above 0.8. From these results, it can be concluded that the reliability of any indicators of the same construct are very good. Furthermore, the AVE values of above 0.5 reflect that the convergent validity is excellent.

After measuring the convergent validity, the discriminant validity was assessed. The measurement was conducted using two different tools: cross loading and the comparison between the constructs with highest value of the root of the AVE. For the former measurement, the requirements of discriminant validity are considered to have been met if the value of cross loading between the indicators that align to identical constructs is always greater than the value of cross loading between the same indicator and the indicators that do not align to the identical constructs. It was concluded that each of the roots of the AVE value were higher than the value of the greatest correlation between constructs. This result therefore confirms the good discriminant validity of all the indicators.

Based on the results of the measurement model analysis, it can be concluded that each of the indicators contained in the model is valid and properly aligned. It can also be concluded that all of the indicators and constructs are suitable to be included in the evaluation of the structural model, which aims to determine the strength of the relationship between each construct of the model. This analysis is conducted by scrutinizing the t-statistics of the constructs.

The t-statistics of constructs differ from the t-statistics of indicators as used in the analysis of outer models. In this case, if an exogenous construct has t-statistics greater than 2.0, that construct is considered to have a significant relationship with its endogenous constructs. The results of the t-statistics analysis are shown in Table 1.

Table.1. Construct's t-statistics Result

\begin{tabular}{lcc}
\hline \multicolumn{1}{c}{ Construct } & Relationship & t-statistics \\
\hline Content ( C ) & $\mathrm{S} \rightarrow \mathrm{C}$ & 3,1836 \\
Accuracy ( A ) & $\mathrm{S} \rightarrow \mathrm{A}$ & 2,6093 \\
Format ( F ) & $\mathrm{S} \rightarrow \mathrm{F}$ & 2,5774 \\
Ease of Use ( E ) & $\mathrm{S} \rightarrow \mathrm{E}$ & 3,5194 \\
Timeliness ( T ) & $\mathrm{S} \rightarrow \mathrm{T}$ & 2,0696 \\
\hline
\end{tabular}

Based on Table 1, it could be concluded that the content, accuracy, format, ease of use, and timeliness factors have affected SCeLE user satisfaction positively. As such, the hypotheses $\mathrm{H} 1, \mathrm{H} 2, \mathrm{H} 3, \mathrm{H} 4$, and $\mathrm{H} 5$ are accepted.

The factor that had the weakest impact on user satisfaction was timeliness. The t-statistics between the timeliness constructs and the SCeLE user satisfaction construct amounted to 2.0696, or close to the minimum limit for the significance of the relationship between constructs. Meanwhile, the factor that had the most dominant effect on SCeLE user satisfaction was the ease of use, with t-statistics of 3.5194. These results provide a useful indication of what should be improved first in order to increase SCeLE user satisfaction.

It can be concluded that this study has obtained similar results to those of the research conducted by Doll and Torkzadeh ${ }^{7}$ in which it was found that there were five factors that affected end-user satisfaction of information systems, namely content, accuracy, format, ease of use, and timeliness. This research has produced different results from the research conducted by Pikkarainen et $\mathrm{al}^{13}$, which indicated that only three factors had a significantly positive effect on the success of the information system; these were content, ease of use and accuracy.

\section{CONCLUSION}

It can be concluded that all of the factors that influence satisfaction with the use of an information system are identical to those which affect SCeLE user satisfaction. It is also confirmed that SCeLE designers must pay attention to the quality requirements of an information system. The results also show that the most dominant factor influencing SCeLE end-user satisfaction is its ease of use. This is because students use SCeLE with the aim of being helped through the learning process, so the user-friendly interface is vital in aiding the students and in increasing SCeLE user satisfaction.

However, there remain some limitations to this study that need to be addressed in future research. First, the distribution of the questionnaire was conducted only during one period of time. Future studies are recommended to collect data in two distinct time periods, once pre-use of SCeLE (beginning of the semester) and once post-use of SCeLE (after mid exam or at the end of the semester), in order to provide additional information about how the usage experience affects the user satisfaction. Second, the model used in this study was the EUCS model, which 
focuses on user satisfaction for information systems. Future research could adopt other models, such as TAM, which focuses on the level of user acceptance of information systems; the DeLone McLean model, which focuses on the level of success of an information system; or other existing models.

\section{ACKNOWLEDGMENTS}

This paper was supported by the Center for Accounting Development (Pusat Pengembangan Akuntansi), Faculty of Economics and Business, Universitas Indonesia.

\section{REFERENCES}

[1] ICAA. Institute of Chartered Accountants Australia, Retrieved on 15 February 2016, http://www.charteredaccountants.com.au/training/resources/elearning.

[2] CPAIRL. Certified Public Accountant Ireland, Retrieved on 21 March 2016, http://www.cpaireland.ie/.

[3] PWC. Price Waterhouse \& Coopers, Retrieved on 20 March 2016, http://www.pwc.com/id.

[4] S. Widanarko. Pedoman Penjaminan Mutu Penyelenggaraan E-Learning. Depok: Badan Penjaminan Mutu Akademik Universitas Indonesia, (2007).

[5] I. G. Basouidis, P. de Lange, T. Suwardy, P. Wells. Accounting Students' Perceptions of Learning Management System: An International Comparison. Accounting Research Journal, 25(2)(2012) 72-86.

[6] C. Loh, D. Wong, A. Quazi, R. P. Kingshott. Re-examining Students' Perception of E-Learning: an Australian Perspective. International Journal of Educational Management, 30(1)(2016) 129-139.

[7] W. J. Doll, G. Torkzadeh. The Measurement of End-User Computing Satisfaction. MIS Quarterly, 12(2)(1988) 259-274.

[8] Triatmoko. Modul Student-Centered e-learning Environment (SCELE UI). Depok: Pelayanan \& Pengembangan Sumberdaya Pembelajaran UI, (2014).

[9] M. B. Romney, J. P. Steinbart. Accounting Information Systems Global Edition. 12. Essex: Pearson, (2012).

[10] J. Sener. OLC's Learning Landscape. Online Learning Consortium Website, Retrieved on 4 January 2016, http://www.onlinelearningconsortium.org (2015).

[11] A. K. M. Najmul Islam. E-Learning System Use and Its Outcomes: Moderating Role of Perceived Compatibility. Telematics and Informatics, 33(1)(2015) 48-55.

[12] eLisa. eLisa UGM, Retrieved on 20 April 2016, http://elisa.ugm.ac.id/.

[13] K. Pikkarainen, T. Pikkarainen, H. Karjaluoto, S. Pahnila. The Measurement of End-User Computing Satisfaction of Online Banking Services: An Empirical Evidence from Finland. International Journal of Bank Marketing, 24(3)(2006) 158-172.

[14] Sutiono, Muldiyanto. Faktor-Faktor yang Mempengaruhi Kepuasan Pengguna E-Learning pada Pusdiklat Anggaran dan Perbendaharaan Tahun 2013. Kajian Akademis BPPK, (2013).

[15] J. Hair. Multivariate Data Analysis: A Global Perspective. 7/E. New York: Apprentice Hall, (2010).

[16] N. Maholtra, D. Birks. Marketing Research: An Applied Approach. Essex: Apprentice Hall, (2007).

[17] S. Yamin, H. Kurniawan. Genarasi Baru Mengolah Data Penelitian dengan Partial Least Square Path Modeling. Jakarta: Salemba Infotek, (2011). 